\title{
Attitudes of Wannabe Kinesiology Students toward School Subjects, School in General and Extracurricular Learning
}

\author{
Saša Milovuković ${ }^{1}$ Hrvoje Sivrić ${ }^{2}$ \\ ${ }^{1}$ University of Zagreb, Faculty of Kinesiology, Zagreb, Croatia \\ ${ }^{2}$ University of Slavonski Brod, Slavonski Brod, Croatia
}

\begin{abstract}
A B S T R A C T
The aim of this research was to determine and explain the attitudes of wannabe students of kinesiology regarding how much they like each school subject, school in general and extracurricular learning. The answers in the questionnaire were given on a semantic differential scale from 1 (100\% repulsive to me) to 5 (I adore it). The study involved 63 wannabe kinesiology students who in 2021 actively prepared for the entrance exam at the Croatian Faculties of Kinesiology. The average age of the respondents was $M=18.83 \pm 1.33$, of which 25 girls and 38 boys. The average rating of all school subjects was $M=3.14$. The highest rated subject was expectedly Physical Education, but the second-best rated subject (geography) had an average rating of $M=3.57$. Significant difference between the rating of each school subject from the average of all school subjects was noticed in chemistry, physics and mathematics (on a negative pole compared to the average) and geography on the positive pole, with a medium to large effect size regarding the difference between arithmetic means. Extracurricular learning was almost zero correlated with all other independent variables. We can conclude that wannabe kinesiology students (aligned with other high school graduates) are not fond of school subjects, nor school in general, but this research shows they do love to learn new things not related to school, so teachers/professors might consider including extracurricular material in teaching to make prescribed material more interesting.
\end{abstract}

Key words: school subjects, Physical Education, wannabe kinesiology students, preparations for the Faculty of Kinesiology, cluster analysis

\section{Introduction}

Today's education focuses on teaching directed to learning outcomes, student competencies, achievements, and the development of concrete and applicable knowledge necessary in the current context of the emergence of new technologies. Although the focus of educational research is often on cognitive factors and students' school achievements, it is also very important for students' emotional and social experiences, as well as their overall school experience ${ }^{1}$. Even though it is a very important aspect of the quality of the education system, satisfaction with the school and quality of school life have been so far relatively rarely examined. Previous research focuses more often on the consequences ${ }^{2,3}$ and the association with school success $^{2-4}$, rather than on the causes and features of that success. School life involves much more, and student's experience and satisfaction with school are important elements of schooling. It should also be noted that the relationship between school achievement and satisfaction is not simple and is very often mediated by the effect of other variables. Thus, Bubić and Goreta ${ }^{1}$ in their research did not find a significant relation between school success and school satisfaction, nor did Raguž ${ }^{5}$. Students graduating from high school face a very demanding transition either to go to university, or to the job market, which is often accompanied by significant stress and worries ${ }^{6-8}$. In view of all the above, it can be concluded that life satisfaction at school must include not only school achievements but also additional, often neglected, factors such as the way students experience themselves, their academic abilities and social skills, and the social environment in which they reside ${ }^{1}$. The activity of secondary school education includes various types and forms of education, training and advanced training accomplished in accordance with the provisions of the Law on Education in Primary and Secondary School ${ }^{9}$. After graduating from high school, there is a possibility of further education at the higher

Received for publication August 5, 2021 
education level. Achieved learning outcomes of students during schooling, as well as their experiences and attitudes about school subjects, school, and extracurricular learning, have consequences on further education that students would like to achieve and on the profession they would like to pursue in the future. According to the research of the Laboratory for Preventive Research, Department of Behavioral Disorders of the Faculty of Education and Rehabilitation in Zagreb ${ }^{10}, 73 \%$ of the 1st to 4 th grade high school students plan to continue their education after high school. Yet only $39 \%$ of students like to go to school, and $52 \%$ of them think that the school encourages them to think and create new ideas. Only $40 \%$ of students find the contents of the school subjects interesting. Similar results were obtained by the Agency for Science and Higher Education on a sample of 13.301 students of all grades of high school according to which $81.3 \%$ of students want to pursue higher education, $14.3 \%$ do not know and $3.9 \%$ do not want to pursue higher education.

Graduates and those who have already passed the state graduation exam (hereinafter final exam), and who wish to become future students of kinesiology (hereinafter wannabe kinesiology students) must pass the entrance exam at the Faculty of Kinesiology, after which they are evaluated and ranked based on success in high school, passed exams at the final exam (Croatian language, mathematics, foreign language), tests of motor skills and on additional student achievements. Given the versatility and multidisciplinarity of the field of kinesiology, wannabe kinesiology students have a desire to acquire desirable competencies that they will later need for self-realization and/or for future career in kinesiology recreation, kinesitherapy, sports and kinesiology education (PE teacher/ professor).

The problem of this research is manifested in the fact that there is an evident deficit of scientific and professional research of the attitudes of high school students, including wannabe students of kinesiology. Therefore, the aim of this research is to determine and explain the attitudes of wannabe students of kinesiology regarding the love of school subjects, school in general and extracurricular learning. Authors assume that the research will show that wannabe kinesiology students prefer PE the most and mathematics the least, and that on average they do not like school subjects and school and learning in general. Authors expect that those who love Physical Education will love both art and music, and those who love mathematics will love both chemistry and physics, with an assumption that it will be the basis for discovering the latent structure of this battery of variables.

\section{Materials and Methods}

\section{Participants}

The sample consisted of 63 wannabe kinesiology students, mostly high school graduates (some have already graduated), who in 2021 were actively preparing for the entrance exam at the Faculties of Kinesiology on Croatia by attending an organized program of at least 25 hours of extracurricular physical education (PE) class, targeting the development of motor skills, in order to prepare for the motor skills exam as an integral part of the entrance exam of the Faculty of Kinesiology in Zagreb, Osijek and Split. The majority of respondents were high school graduates aged 18-19 (84\%), and the rest were young athletes who had already finished high school but had not yet passed final exam, or for some other reason now decided to enroll to the Faculty of Kinesiology. The average age of wannabe kinesiology students was $\mathrm{M}=18.83 \pm 1.33$, both sexes $(25 \mathrm{~F}, 38 \mathrm{M})$, predominantly from Zagreb (37\%), but also from all other parts of Croatia, from Orahovica to Split, with two graduates from Bosnia and Herzegovina.

\section{Instruments}

The respondents filled out a questionnaire consisting of 5 segments, a part of which, about school subject attitudes, was analyzed for the purposes of this paper. The research was conducted just before the beginning of the first class of the PE preparation program. All respondents were of legal age at the time of completing the questionnaire and gave written consent to participate in the survey. Completing the whole questionnaire took 10-15 minutes. The questionnaire was not anonymous due to the need for subsequent data collection, but respondents were guaranteed that only the first author of this paper had access to their personal data.

\section{Variables}

The part of the questionnaire on attitudes about school subjects consisted of 12 questions whose answers were on the semantic differential scale (SDS) ${ }^{11}$ from 1 to 5 . Respondents were asked to express the strength of how much they like or dislike a particular school subject, how much they like or dislike school in general, and how much they like or dislike to learn other non-school related things (extracurricular learning). The answers offered were: $1-100 \%$ repulsive to me, 2 - I don't like it, 3 - I'm not sure, 4 - I love it, $5-\mathrm{I}$ adore it. The first 10 independent variables were school subjects common to all secondary schools in the Republic of Croatia: CRO (Croatian language), MAT (mathematics), BIO (biology), CHE (chemistry), PHY (physics), PE (physical education), MUS (music) ), ART (art), HIS (history), GEO (geography), to which two variables have been added: SCHOOL (how much they like school in general) and OTHER (how much they like to learn other things unrelated to school). The authors calculated and added the AVG variable to this battery of 12 variables, which expresses an average score of the 10 school subjects i.e., it gives us an insight into how much wannabe kinesiology students like school subjects on average. Therefore, the total number of independent variables were increased to 13 . 


\section{Methods}

Within the descriptive statistics, the basic statistical parameters (mean, median, minimum, maximum, standard deviation, confidence limits for mean, skewness, kurtosis) were calculated, including the Shapiro-Wilk test of distribution normality. Frequency histogram and normal P-Plots were visually inspected. The distribution of arithmetic means and standard deviations of 13 independent variables is shown with the Box and Whiskers plot. Given the results obtained, parametric statistics was used for data processing, but keeping in mind the limitations of the SDS/Likert-type scales when making conclusions, so parallel non-parametric statistical methods/analysis were conducted. To test the differences between arithmetic means, instead of using repeated measures ANOVA, after which the statistical significance of 66 pairs of variables of post-hoc test should be analyzed and interpreted, the authors opted for a simpler approach. Authors assumed that no school subject on average differs from the average of all other school subjects, as reference value. For this purpose, the average of the variable AVG was taken as a reference value for comparison among school subjects, and the averages of each school subject were tested in relation to this reference value. Thus, the greater the difference between means of an individual school subject with the reference value, the students will more or less like that specific subject rather than other subjects (on average). The differences between arithmetic means of school subjects were tested with t-test for dependent samples with Bonferroni correction for family-wise error rate (FWER) control, including Sign-test and Wilcoxon matched pairs test as non-parametric control tests. For statistically sig- nificant differences, effect size is given. To explore the relations between school subjects, the Pearson intercorrelation matrix was calculated, including Spearman rank order correlation as a non-parametric control method. In order to identify the potential existence of latent dimensions of independent variables, Kaiser-Meyer-Olkin test (KMO) was conducted to check the correlation matrix for factor analysis. Since the KMO was not satisfactory, the variables were compared based on Euclidean distances, with the Ward's method i.e., via a joining tree cluster analysis. The data were processed by the software package TIBCO Statistica 13.5 and Microsoft Excel 2017.

\section{Results and Discussion}

\section{Descriptive statistics}

Table 1 shows the descriptive parameters of all 13 independent variables. The first 10 variables (school subjects) are ranked according to their size of the arithmetic mean, which expresses how much on average the respondents like a particular school subject. The bottom of the table consists of the remaining three variables that show the average love of all 10 school subjects (AVG), how much respondents like school in general (SCHOOL) and how much they like to learn other things unrelated to school (OTHER). As shown in the table, the arithmetic means of individual school subjects are relatively low and vary from Min=2.14 to $\mathrm{Max}=3.57$, not taking into account the extreme value of $\mathrm{PE}(\mathrm{M}=4.90)$. The average score for all 10 subjects is $\mathrm{M}=3.14$, which is the value of the variable $\mathrm{AVG}$, but it should be borne in mind that the average score of

TABLE 1

DESCRIPTIVE STATISTICS OF INDEPENDENT VARIABLES, NORMALITY

\begin{tabular}{|c|c|c|c|c|c|c|c|c|c|c|c|}
\hline $\mathrm{n}=63$ & Mean & Median & Min & Max & St.dev. & $\begin{array}{c}\text { M conf. } \\
-95 \%\end{array}$ & $\begin{array}{c}\text { M conf. } \\
95 \%\end{array}$ & Skew. & Kurt. & Shapiro-Wilk $p$ & t-test AVG \\
\hline $\mathrm{PE}$ & 4.90 & 5.00 & 4.00 & 5.00 & 0.30 & 4.83 & 4.98 & -2.83 & 6.18 & 0.00 & - \\
\hline GEO & 3.57 & 4.00 & 1.00 & 5.00 & 1.15 & 3.28 & 3.86 & -0.75 & 0.00 & 0.00 & * 3.58 \\
\hline MUS & 3.35 & 3.00 & 1.00 & 5.00 & 1.28 & 3.03 & 3.67 & -0.27 & -0.97 & 0.00 & 1.43 \\
\hline $\mathrm{BIO}$ & 3.24 & 3.00 & 1.00 & 5.00 & 1.04 & 2.98 & 3.50 & -0.68 & 0.03 & 0.00 & 0.81 \\
\hline HIS & 3.16 & 3.00 & 1.00 & 5.00 & 1.22 & 2.85 & 3.47 & -0.15 & -0.80 & 0.00 & 0.15 \\
\hline CRO & 3.16 & 3.00 & 1.00 & 5.00 & 0.87 & 2.94 & 3.38 & -0.47 & 0.42 & 0.00 & 0.17 \\
\hline $\mathrm{ART}$ & 3.06 & 3.00 & 1.00 & 5.00 & 1.33 & 2.73 & 3.40 & -0.08 & -1.10 & 0.00 & -0.54 \\
\hline MAT & 2.62 & 2.00 & 1.00 & 5.00 & 1.04 & 2.36 & 2.88 & 0.30 & -0.60 & 0.00 & $*-4.37$ \\
\hline PHY & 2.19 & 2.00 & 1.00 & 5.00 & 1.09 & 1.92 & 2.47 & 0.69 & -0.20 & 0.00 & $*-7.73$ \\
\hline CHE & 2.14 & 2.00 & 1.00 & 5.00 & 0.96 & 1.90 & 2.39 & 0.71 & 0.17 & 0.00 & * -9.53 \\
\hline AVG & 3.14 & 3.10 & 1.80 & 4.00 & 0.48 & 3.02 & 3.26 & -0.36 & 0.14 & 0.22 & - \\
\hline SCHOOL & 3.27 & 3.00 & 1.00 & 5.00 & 0.87 & 3.05 & 3.49 & -0.72 & 0.67 & 0.00 & 1.31 \\
\hline OTHER & 4.54 & 5.00 & 3.00 & 5.00 & 0.59 & 4.39 & 4.69 & -0.88 & -0.17 & 0.00 & * 14.87 \\
\hline
\end{tabular}

AVG - average of all 10 school subjects; SCHOOL - how much the respondents love school in general; OTHER - how much respondents like to learn other things unrelated to school - love of extracurricular learning; * - statistically significant values after Bonferroni correction for FWER control $(\mathrm{p}<0.0045)$. 
the variable PE makes it outlier, which significantly raises the average of all school subjects. Given the nature of the population chosen, it is not surprising that $\mathrm{PE}$ is an outlier variable. Excluding PE, the average score given by wannabe kinesiology students to all other subjects is only $\mathrm{M}=2.55$, which is the answer at the level of "I don't like that subject" to "I'm not sure". 95\% confidence limits of mean vary from $\mathrm{Min}=0.44$ (AVG) to $\mathrm{Max}=0.65$ (MUS), which is not shown in Table 1, but can be calculated from it. These data tell us that we can say with great confidence that wannabe kinesiology students are neither fans of school subjects nor school in general $(\mathrm{M}=3.27)$. Although this could be attributed to the specifics of the selected population, a 2020 survey by the Croatian Institute of Public Health concludes that the proportion of male and female students who like school is low. In boys it is $5-13 \%$ at the age of $11-15$ years, and in girls $5-20 \%$ in the same age group. The paper also states that the worrying data are that among students aged 13, Croatia was in the penultimate place in 2014, and in 2018 it was in the last place with the lowest share of students who answered that they really like school. The proportion of students who feel burdened by the school (quite a lot or a lot) increases from $23 \%$ at the age of 11 , over $41 \%$ at the age of 13 and decreases to almost $33 \%$ at the age of $15 .{ }^{12}$ The study from $2004^{13}$ in Virovitičko-podravska county showed that the grade that high school students gave for the satisfaction with their school program is 3 (on the scale $1-5$ ). The same study showed that according to the teachers, the main reason for students' poor performance in school is the lack of interests in a subject. These results align with the presented findings of this study, thus the fact that the wannabe kinesiology students in this research are not fond of the school subjects and the school in general is not the specificity of the wannabe kinesiology students, rather a much broader problem that the education system has for a fairly long time. Times are changing much faster than the education system is responding to change.

Given the analyzed population, wannabe kinesiology students expectedly prefer PE the most. Actually, they adore PE $(\mathrm{M}=4.90)$. Almost all respondents gave the maximum score to this subject ("I adore it"), so due to poor metric characteristics, this variable was analyzed only at the level of descriptive statistics and excluded from further analysis. However, it is an intriguing fact that six wannabe kinesiology students gave this subject a score of 4 , which means they do love PE, but do not adore PE. For potentially future PE professors/teachers and/or kinesiology professors and/or sports coaches, this is an unexpected and very interesting data for the authors. Whether the reason is the previous bad experience with PE professor (teacher), inappropriate PE curriculum by the students' criteria, or something third, should certainly be investigated in more detail in future surveys. Respondents least like chemistry $(\mathrm{M}=2.14)$, physics $(\mathrm{M}=2.19)$ and mathematics $(\mathrm{M}=2.62)$, which is an expected but still worrying fact, since these are the basic subjects from which biomechanics, physiology and quantitative methods are derived; the courses which are an integral part of the curriculum at the Faculties of Kinesiology in Croatia. Completely unexpectedly, wannabe kinesiology students love (except PE) geography the most $(\mathrm{M}=3.57)$. This average is relatively low in absolute terms, which indicates that the respondents are not excessive fans of this subject, yet it is still a second-ranked subject in the battery of all 10 school subjects. Since the authors are encountering this data for the first time, it would certainly be interesting to explore where this love of young athletes for geography comes from, and whether it can be useful for the staff that works with those students now and in the future.

One of the most interesting data derived from Table 1 is the very high average of the OTHER variable $(\mathrm{M}=4.54)$, which tells us that young athletes are not lazy for learning, yet only do not like to learn the material prescribed by the curriculum. As many as $59 \%$ of respondents gave the maximum score ("I adore it") when asked how much they like to learn other things unrelated to school, and only $5 \%$ gave score 3 ("I don't know"), while the remaining $36 \%$ of respondents gave a score of 4 ("I love it"). Obviously, the interests of this subpopulation of young athletes are very poorly covered by the high school curriculum, which is also valuable information for staff working with this population in high school or will work in higher education. Teachers and professors might consider including extracurricular material in teaching to make prescribed material more interesting.

Figure 1 shows the Box and Whiskers Plot of arithmetic means and standard deviations of variables ranked by arithmetic mean size. It can be seen from the plot that PE is ranked far above all other subjects, followed by a very steep decline towards the next highest ranked school subject, which is geography. Geography is followed by a much milder decline to music, followed by an even milder and almost linear decline to biology, history, Croatian language, and art. This is followed by another linear and steep decline towards mathematics and physics, and the curve ends with a slight decline towards chemistry. From this plot, three groups of school subjects can be distinguished

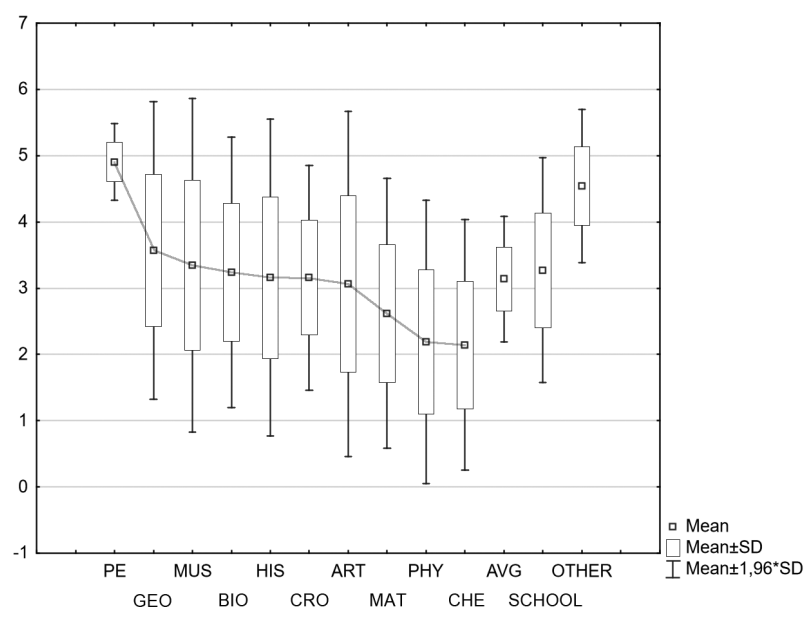

Fig. 1. Box and Whisker plot. 
regarding the size of arithmetic means. The first group consists only of $\mathrm{PE}$, which is positioned far above all subjects and with the least dispersion of results. The second group consists of six school subjects of almost equal arithmetic means and standard deviations, which have in common that they have no points of contact with mathematics. Geography deviates to a lesser extent from this group, with a slightly higher average than the rest of this group of subjects. The third group consists of chemistry and physics, and partly mathematics, which is located exactly between the second and third groups of subjects. Common to the third group of subjects is that mathematics is the basis of all these subjects.

The Shapiro-Wilk distribution normality test (Table 1) shows that all variables (except AVG) significantly deviate from the normal distribution, as expected, since all variables (except AVG) are on a semantic differential scale, and this scale is not sensitive enough to distribution normality tests. By inspecting the frequency histograms and normal P-Plot, the authors concluded that no variable in the form of distribution deviates significantly from the normal distribution, except to some extent the variable OTHER. Likewise, skewness and kurtosis in all variables are within \pm 1 (except kurtosis of ART variable, $\mathrm{a}_{4}=1.10$ ). As an additional control, in addition to the arithmetic mean, the median was calculated, and the table shows that both parameters match in all variables, except for a small deviation in the variable MAT $(\mathrm{M}=2.62, \mathrm{Me}=2)$.

\section{Differences between arithmetic means of school subjects}

An important question that arises from the obtained means is whether the observed internal differences between the arithmetic means of the analyzed variables can be generalized to the entire population of wannabe kinesiology students. T-test for dependent samples was used to analyze the significance of the differences obtained. The last column in Table 1 shows t-values, and the asterisks indicate statistically significant t-values after Bonferroni correction ( $p<0.0045)$. As shown in the table, it is hardly a coincidence that geography is the favorite subject among the wannabe kinesiology students and especially love of extracurricular learning, as well as that chemistry, physics and math are the subjects they like the least. The effect sizes for the mentioned variables $(\mathrm{p}<0.0045)$ are medium to very large: $\mathrm{Es}=0.45(\mathrm{GEO})$, $\mathrm{E}_{\mathrm{s}}=-0.54(\mathrm{MAT}), \mathrm{Es}=-0.97(\mathrm{PHY})$ and $\mathrm{E}_{\mathrm{s}}=-1.21(\mathrm{CHE})$. The effect size of the OTHER variable is very large $\mathrm{Es}=1.87$. In conclusion, observed differences between liking of different school subjects are not just significant, but large or very large as well, which gives us a good and reliable insight into attitudes of wannabe kinesiology students toward school. Nonparametric tests for data validity control (Sign-test and Wilcoxon matched pairs test) showed that the same variables as in the t-test were significantly different at $\mathrm{p}<0.000$.

\section{Correlations}

The intercorrelation matrix is shown in Table 2. The Pearson correlation coefficient was used as a measure of correlation between variables. Correlations significant at $\mathrm{p}<0.05$ are marked with one asterisk, and at $\mathrm{p}<0.01$ are marked with two asterisks. All significant correlations are positive. At first glance, the most noticeable are the positive and significant correlations of the AVG variable with all school subjects. The variable AVG was obtained by a linear combination of all 10 variables of school subjects, which limits the interpretation of these coefficients. However, it is still noticeable that wannabe kinesiology students who like the most all subjects on average at the same

TABLE 2

PEARSONS CORRELATION MATRIX OF INDEPENDENT VARIABLES

\begin{tabular}{|c|c|c|c|c|c|c|c|c|c|c|c|c|}
\hline $\mathrm{n}=63$ & $\mathrm{CRO}$ & MAT & $\mathrm{BIO}$ & $\mathrm{CHE}$ & PHI & MUS & $\mathrm{ART}$ & HIS & GEO & AVG & SCHOOL & OTHER \\
\hline CRO & 1.00 & -0.08 & 0.24 & 0.07 & 0.07 & 0.07 & 0.02 & -0.15 & 0.17 & $0.26^{*}$ & 0.24 & 0.05 \\
\hline MAT & -0.08 & 1.00 & -0.03 & 0.09 & $0.36^{* *}$ & 0.14 & 0.05 & 0.12 & 0.12 & $0.45^{* *}$ & 0.22 & 0.10 \\
\hline $\mathrm{BIO}$ & 0.24 & -0.03 & 1.00 & $0.29 *$ & 0.16 & -0.14 & 0.12 & 0.11 & 0.07 & $0.42^{* *}$ & -0.02 & 0.13 \\
\hline $\mathrm{CHE}$ & 0.07 & 0.09 & $0.29 *$ & 1.00 & 0.22 & 0.15 & $0.27 *$ & 0.14 & 0.04 & $0.56^{* *}$ & 0.15 & 0.06 \\
\hline PHY & 0.07 & $0.36^{* *}$ & 0.16 & 0.22 & 1.00 & -0.15 & 0.06 & 0.16 & 0.12 & $0.46^{* *}$ & -0.02 & -0.14 \\
\hline MUS & 0.07 & 0.14 & -0.14 & 0.15 & -0.15 & 1.00 & $0.51 * *$ & 0.03 & 0.03 & $0.48 * *$ & 0.22 & 0.13 \\
\hline $\mathrm{ART}$ & 0.02 & 0.05 & 0.12 & $0.27 *$ & 0.06 & $0.51^{* *}$ & 1.00 & 0.16 & 0.17 & $0.62 * *$ & 0.20 & 0.02 \\
\hline HIS & -0.15 & 0.12 & 0.11 & 0.14 & 0.16 & 0.03 & 0.16 & 1.00 & $0.67 * *$ & $0.45^{* *}$ & $0.40 * *$ & -0.17 \\
\hline GEO & 0.17 & 0.12 & 0.07 & 0.04 & 0.12 & 0.03 & 0.17 & $0.67^{* *}$ & 1.00 & $0.37 * *$ & $0.36 * *$ & -0.08 \\
\hline AVG & $0,27^{*}$ & $0,42^{* *}$ & $0,39 * *$ & $0,51 * *$ & $0,45^{* *}$ & $0,43^{* *}$ & $0,60 * *$ & $0,56 * *$ & $0,57 * *$ & 1,00 & $0,43 * *$ & 0,04 \\
\hline SCHOOL & 0.24 & 0.22 & -0.02 & 0.15 & -0.02 & 0.22 & 0.20 & $0.40 * *$ & $0.36 * *$ & $0.37 * *$ & 1.00 & -0.04 \\
\hline OTHER & 0.05 & 0.10 & 0.13 & 0.06 & -0.14 & 0.13 & 0.02 & -0.17 & -0.08 & 0.07 & -0.04 & 1.00 \\
\hline
\end{tabular}

*statistically significant correlations with significance level p <0.05;

$* *$ - statistically significant correlations with significance level $\mathrm{p}<0.01$ 
time like art $(r=0.60)$, geography $(r=0.57)$ and history $(r=0.56)$ the most. Significant relation of the AVG variable is the weakest with the Croatian language $(r=0.27)$. The correlation of the AVG variable with the remaining two variables is even more interesting. The relationship between the AVG and SCHOOL is unexpectedly low $(r=0.43)$ due to the nature of the variables themselves, which explains only $18 \%$ of the common variance of these variables. This raises a serious question for what reasons is there a relatively large number of students who love school in general, but at the same time do not love school subjects (on average)? Clearly, school subjects itself do not provide good explanation why children like to go to school. The research of the Agency for Science and Higher Education from $2017^{14}$ shows that $61.1 \%$ of high school students fully agree that other things (resourcefulness, personal connections, parents...) are more important for enrollment at a university in Croatia than the ability to learn. All of the above data should worry the scientific community and especially school staff.

Furthermore, the AVG variable is almost zero correlated $(r=0.04)$ with the OTHER variable (how much respondents like to learn other non-school related things) i.e., the OTHER variable is almost zero correlated with all other independent variables, which tells us that those wannabe kinesiology students who like extracurricular learning are not necessarily those respondents who prefer school in general, nor any school subject. So, we might conclude that the love of learning in wannabe kinesiology students is not a factor that can be assessed based on the love of learning within the education system. Learning for school and learning for life are separate dimensions and it would certainly be interesting to explore whether this also applies to the general population of schoolchildren. However, it is an intriguing fact that those students who like school the most are generally those students who like history $(r=0.40)$ and geography $(r=0.36)$ the most. These subjects teach students about the world that surrounds us, or the world that has been surrounding us. Although the correlation coefficients are moderate, these correlations are hardly coincidental $(\mathrm{p}<0.01)$, so the question arises what the possible cause of these relations is. Authors speculate that because these subjects require much more of memorizing a lot of facts, rather than solving problems and drawing conclusions, this might be a suppressor variable that connects liking the school in general and liking history and geography. Students who do not lack a motivation for learning a lot of facts might be the one with greater motivation for school in general. Namely, it is known that motivation to learn is one of the main predispositions for school success, which is confirmed by the findings of various authors. ${ }^{15,16,17}$

Of the remaining significant correlations, pairs of variables are noticeable. Mathematics and physics $(\mathrm{r}=0.36)$, music and art $(r=0.51)$, geography and history $(r=0.67)$, chemistry and biology $(\mathrm{r}=0.29)$ and chemistry and art $(r=0.27)$. Apart from the relation between chemistry and art, all other relations are logical, because the subjects are consistent. The only subject that does not have a significant correlation with any other subject is the Croatian language. It is in almost zero correlation with all subjects, except for biology $(r=0.26)$, which is on the verge of being significant at the error rate $\mathrm{p}<0.05$. Thus, the Croatian language did not prove to be consistent with any other general school subject, although the author's assumption is that it would be positively correlated with English language, which in this questionnaire is not placed as a subject common to all high schools in Croatia. The reason why the authors left it out lies in the fact that some students learn German, Italian, or some other language as the only foreign language. However, all languages could have been reduced to one common variable "Foreign language", which is a methodological oversight of the authors.

The parallel nonparametric method Spearman rank order correlation gives very similar correlation coefficients, without significant differences in relation to the matrix of Pearson correlation coefficients.

\section{Cluster analysis}

Pairs of correlated school subjects, but with very low correlation coefficients with other school subjects indicate the existence of a latent structure behind attitudes about school subjects, school in general and learning other things unrelated to school. The relationships between the variables were analyzed based on Euclidean distances and with Ward's method i.e., using joining tree cluster analysis. The joining tree diagram is shown in Figure 2. It is clear from the diagram that school subjects at the top of the hierarchy are grouped into two clusters of subjects i.e., two groups of wannabe kinesiology students who have completely different views on which subjects they prefer, or not. The first group consists of chemistry, physics and mathematics - a cluster consisting of subjects more inclined towards science subjects based in mathematics. These subjects are the ones that cannot do without formulas and their solution, which is obviously a major discriminatory factor among future students of the Faculty of Kinesiology.

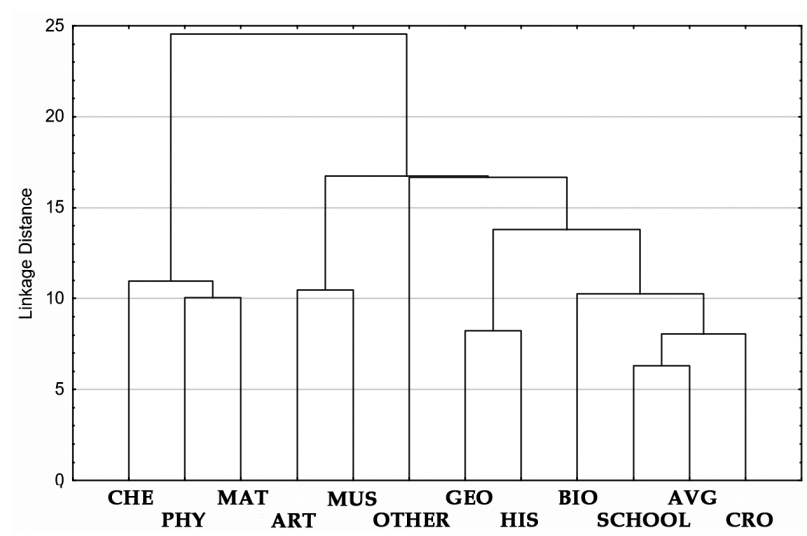

Fig. 2. Cluster analysis tree diagram, Ward's method, and Euclidean distances. 
The second group consists of all other subjects, including average of all subjects (AVG), love of school in general (SCHOOL) and love of extracurricular learning (OTH$\mathrm{ER})$. It can be seen from the diagram that the OTHER variable is largely independent of all other variables, indicating the existence of a special subgroup of wannabe kinesiology students who prefer to learn things unrelated to school rather than any subject in school and school in general. However, at higher levels of tree hierarchy this variable deviates significantly from science subjects with a mathematical basis and leans towards all other variables. Thus, we can conclude that respondents who like science subjects with a mathematical background are not respondents who like extracurricular learning, which is odd, interesting, for authors unexpected, and certainly worth of investigating in some further research what are the possible reasons for such phenomenon. In the second group of variables, pairs of school subjects accordant with the correlation matrix are visible at the first level of the tree hierarchy. Art and music could be called a group of artistic social subjects, which, like the OTHER variable, stands out from the rest of this cluster and merges with them into one cluster at the same level as the OTHER variable. History and geography form another visible and logical cluster. History is formally classified in the group of social subjects, and geography in the group of natural sciences, but these two subjects are studied together at two faculties in Croatia during higher education, namely History and Geography (Faculty of Philosophy) and Geography and History (Faculty of Natural Sciences and Mathematics). Both subjects study the world around us (or previously around us), so it is no wonder there is a subgroup of respondents who single out history and geography as subjects they love equally.

The Croatian language is closest to those who like on average all subjects (AVG), following school in general (SCHOOL), and finally to biology. These four variables form a separate cluster of variables that is somewhat more difficult to interpret. Due to the specifics of the selected population, this cluster of variables could be interpreted as variables relevant to the entrance exam, as well as to the studying at the Faculty of Kinesiology. The Croatian language is an integral part of the final exam for all high school graduates who pursue higher education at the Faculty of Kinesiology. The entrance exam for the Faculties of Kinesiology also looks at average grades from all grades of high school, which is very close to what the AVG variable estimates. Until recently, biology was also a subject that had to be passed at the state graduate exam in case of taking the entrance exam for the Faculty of Kinesiology (yet no longer), but due to the very nature of the faculty that studies human movement at its core, it is a fundamental subject for kinesiology. And finally, how much wannabe kinesiology students love formal education (SCHOOL) is certainly also important (not only for the studying of kinesiology), as they continue with formal education, this time in college.

\section{Advantages and limitations}

The biggest advantage of this paper is the fact that there is no research known to the authors conducted in this way and that there are no previous studies done on the wannabe population of kinesiology students. According to Novak and Bernstein ${ }^{18}$ "In addition to the formation of teaching practice, new teachers shape their personal identity as teachers. To that end, teachers must take a proactive stance in learning." Therefore, everyone who works with this population in high schools, especially PE professors, as well as professors at the Faculties of Kinesiology can find potentially valuable information in this paper that will help them better understand this subpopulation of young athletes. We should also bear in mind the limitations of this research, the biggest of which is the fact that the first author also conducted a survey of these respondents, but also participated in classes as their PE professor (teacher), preparing them for the entrance exam for the Faculty of Kinesiology. Although still very young and inexperienced, 10 participants already finished high school, so it is possible that their views about school subjects, school in general and extracurricular learning has been changed. Additionally, due to the non-anonymity of the questionnaire and the 1st authors involvement with participants, it is possible that certain respondents wanted to improve their self-image and therefore it is possible that wannabe kinesiology students prefer school subjects and school in general even less then discovered in this paper. Another limitation is that the authors did not include a foreign language in the survey questionnaire, so it is possible to draw only speculative conclusions for this subject. Although the results on the SDS/Likert-type scale suffer from standard methodological flaws, which is a potential limitation of this research, in this paper, wherever possible, control tests were performed to confirm obtained results (Bonferroni FWER correction, parallel non-parametric tests, effect size...), and thus the potential limitations turned into advantages of this research.

\section{Conclusion}

Sixty-three wannabe kinesiology students were interviewed with a questionnaire of attitudes about how much they like certain common high school subjects, school in general, and how much they like to learn other things unrelated to school. The study confirmed hypothesis that this subpopulation of young athletes is not a fan of school subjects nor school in general. Although previous research about attitudes of students toward school is scanty, they show these findings to be aligned with previous research, so the fact that the wannabe kinesiology students are not fond of the school subjects and the school in general is not the specificity of this population, rather a much broader problem of the education system. Apart from PE, this subpopulation of young athletes likes geography the most among all school subjects, which is hard-to-explain phenomenon for authors, yet potentially highly valuable information for staff working with this population. Wannabe 
kinesiology students love chemistry, physics, and mathematics the least, which was expected, but also worrying, as these are the core subjects from which physiology, biomechanics and quantitative methods emerge, and are courses taken during kinesiology studies. This hypothesis is partially confirmed since the authors assumed the mathematics is the school subject wannabe kinesiology students like the least. These data show big disproportion of what subjects wannabe kinesiology students dislike in high school and what subjects are the basis of the multidisciplinary field of kinesiology. If these results were to be confirmed in some further research, Faculties of Kinesiology could consider whether it would be a good practice to replace Croatian and a foreign language with chemistry and physics as subjects needed to be passed and graded at the final exam as the scores counted in the entrance exam at the Faculties of Kinesiology. Students who like school in general don't like it (just) because they like school subjects. Only $18 \%$ of the common variance between these two variables opens free space for further research on why loving school subjects is not a sufficient reason to love school in general. School life is clearly much more than just school subjects; thus, it is a straight message to schools that if they want to make the school more attractive to students, improving methods and materials (even extracurricular) of each subject might not be enough. Still, wannabe kinesiology students who love school the most are those who love history and geography the most. The cause of this relation might be the fact that because these subjects require much more of memorizing a lot of facts, rather than solving problems and drawing conclusions, it might be a suppressor variable that connects liking the school in general and liking history and geography. Students who do not lack a motivation for learning (which is a known predictor of school success by previous research), especially learning a lot of facts, might be the students with greater motivation for school in general. However, the OTHER variable is in almost zero correlations with almost all variables from which we conclude that loving the school subjects and school in general is not a good predictor of how students will lead their later life i.e., how much they will want to learn some other things, not prescribed by the curriculum.

\section{R E F E R E N C E S}

1. BUBIĆ A, GORETA I, Psihologijske teme, 24 (2015) (3). doi:doi.org/10.31820/pt. — 2. HUEBNER ES, MCCULLOUGH G, The Journal of Educational Research, 93 (5) (2000) 331. doi:10.1080/00220670009598725. — 3. VERKUYTEN M, THIJS J, Social Indicators Research, 59/2 (2002) 203. doi:10.1023/A:1016279602893. - 4. NIKČEVIĆ-MILKOVIĆ A, JERKOVIĆ A, BILJAN E, Napredak: časopis za pedagogijsku teoriju i praksu, 154 (2014) 375. https://hrcak.srce.hr/138857. — 5. RAGUŽ L, Školski uspjeh srednjoškolaca, neki njegovi korelati i odrednice. MS Thesis. (University of Zagreb, Zagreb, 2017). — 6. CREED PA, MULLER J, PATTON W, Journal of Adolescence, 26 (2003) 295. doi:10.1016/S0140-1971(03)00015-0. — 7. GALL TL, EVANS DR., BELLEROSE S, Journal of Social and Clinical Psychology, 19 (2000) 544. doi:10.1521/ jscp.2000.19.4.544. - 8. GALOTTI KM, Journal of Educational Psychology 91 (1999) 379. doi:10.1037/00220663.91.2.379. - 9. NARODNE NOVINE, 87/08, 86/09, 92/10, 105/10, 90/11, 5/12, 16/12, 86/12, 126/12, 94/13, 152/14, 07/17, 68/18, 98/19, 64/20, https://www.zakon. hr/z/317/Zakon-o-odgoju-i-obrazovanju-u-osnovnoj-i-srednjoj-\%C5\%A1koli. - 10. NOVAK M, Pozitivan razvoj adolescenta grada Zagreba. Projekt laboratorija za prevencijska istraživanja, Edukacijsko-rehabilitacijski fakultet, Sveučilište u Zagrebu, https://mzo.gov.hr/UserDocsImages//dokumenti/ Vijesti/2019/2019//PRAG\%20-\%20HR\%20MZO\%20sazetak\%20 panelisti.pdf. - 11. OSGOOD C, Psychol Bull, 49(3) (1952) 197. doi:10.1037/h0055737 — 12. JOKIĆ B, Preliminarni rezultati projekta: Analiza stanja i potreba u srednjoškolskom odgoju i obrazovanju vezanih uz informiranje o visokoškolskim izborima i postupcima upisa na studijske programe preko Nacionalnog informacijskog sustava prijava na visoka učilišta (NISpVU) (Agencija za znanost i visoko obrazovanje, Zagreb, 2018), https://www.idi.hr/ wp-content/uploads/2018/06/PRIKAZ_ZA_MEDIJE-boas_final.pdf. - 13. BIONDIC-IVANKOVIC P, BRLAS S, MATOŠEVIC LJ, POFUK LJ, ŠTETIC I, Život i škola : časopis za teoriju i praksu odgoja i obrazovanja, 12 (2/2004) 55. https://hrcak.srce.hr/25506. - 14. CAPAK K, Istraživanje o zdravstvenom ponašanju učenika - HBSC 2017/2018 (Hrvatski zavod za javno zdravstvo, Zagreb, 2020). https://www.hzjz.hr/wp-content/uploads/2020/05/ HBSC_2018_HR_-1.pdf. - 15. FREUDENTHALER HH, SPINATTH B $\bar{B}$, NEUBAUER AC, European Journal of Personality, 22 (2008) 231. doi:10.1002/per.678. — 16. MURATOVIĆ L, Školski vjesnik: časopis za pedagoška i školska pitanja, 62 (2013) 209. https://hrcak.srce.hr/105321. — 17. WONG MM, CSIKSZENTMIHALYI M, Journal of Personality, 59 (1991) 539. doi:10.1111/J.1467-6494.1991. TB00259.X. - 18. NOVAK D, BERNSTEIN E, International Journal of Physical Education, 52 (2015) 2.

\section{S. Milovuković}

University of Zagreb, Faculty of Kinesiology, Horvaćanski zavoj 15, 10110 Zagreb, Croatia

e-mail:email@sasamilovukovic.from.hr 
STAVOVI STUDENATA KOJI ŽELE STUDIRATI KINEZIOLOGIJU PREMA ŠKOLSKIM PREDMETIMA, ŠKOLI OPĆENITO I IZVANNASTAVNOM UČENJU

\section{S A Ž E T A K}

Cilj je ovog istraživanja bio utvrditi i objasniti koliko maturanti i oni koji su već položili državnu maturu, a koji imaju želju postati budući studenti kineziologije, vole opće školske predmete, školu općenito i učenje izvan propisanog kurikuluma. Odgovori su se davali na semantički diferencijalnoj skali od 1 ( $100 \%$ mi je odbojno) do 5 (obožavam). U istraživanju je sudjelovalo 63 budućih studenta kineziologije koji su se tijekom 2021. aktivno i organizirano pripremali za

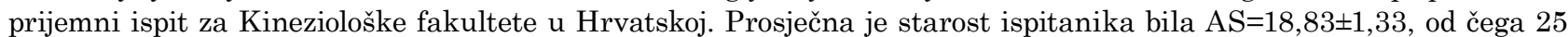
djevojaka i 38 mladića. Od prosjeka svih školskih predmeta, statistički značajno su odstupali predmeti (ne računajući TZK koji je „outlier“) geografija, kemija, fizika, matematika, a posebno učenje izvan propisanog kurikuluma, uz srednju do veliku veličinu efekta razlike aritmetičkih sredina. Oni učenici koji najviše vole školu ujedno najviše vole povijest $(\mathrm{r}=0,40)$, geografiju $(\mathrm{r}=0,37)$ i sve predmete u prosjeku $(\mathrm{r}=0,36)$. Prosječno voljenje svih školskih predmeta je u neočekivano niskoj korelaciji s voljenjem škole općenito $(\mathrm{r}=0,43)$. Varijable su se klasterirale $\mathrm{u}$ dva osnovna klastera: grupu predmeta imaju matematičku podlogu (matematika, fizika, kemija) i grupu svih ostalih školskih predmeta, uključujući i voljenje škole općenito, kao i voljenje drugih stvari nevezano za školu. Možemo zaključiti kako potencijalni studenti kineziologije nisu ljubitelji školskih predmeta, niti škole općenito, ali vole učiti nove stvari nevezane za školu, tako da bi učitelji/profesori mogli razmisliti o tome da u nastavu ubace ekstrakurikularne materijale i metode s ciljem da propisane teme učine zanimljivijima. 
